\title{
Introduction: the politicisation of permanent crisis in Europe
}

Citation for published version (APA):

Voltolini, B., Natorski, M., \& Hay, C. (2020). Introduction: the politicisation of permanent crisis in Europe. Journal of European Integration, 42(5), 609-624. https://doi.org/10.1080/07036337.2020.1792460

Document status and date:

Published: 03/07/2020

DOI:

10.1080/07036337.2020.1792460

Document Version:

Publisher's PDF, also known as Version of record

Document license:

Taverne

Please check the document version of this publication:

- A submitted manuscript is the version of the article upon submission and before peer-review. There can be important differences between the submitted version and the official published version of record.

People interested in the research are advised to contact the author for the final version of the publication, or visit the DOI to the publisher's website.

- The final author version and the galley proof are versions of the publication after peer review.

- The final published version features the final layout of the paper including the volume, issue and page numbers.

Link to publication

\footnotetext{
General rights rights.

- You may freely distribute the URL identifying the publication in the public portal. please follow below link for the End User Agreement:

www.umlib.nl/taverne-license

Take down policy

If you believe that this document breaches copyright please contact us at:

repository@maastrichtuniversity.nl

providing details and we will investigate your claim.
}

Copyright and moral rights for the publications made accessible in the public portal are retained by the authors and/or other copyright owners and it is a condition of accessing publications that users recognise and abide by the legal requirements associated with these

- Users may download and print one copy of any publication from the public portal for the purpose of private study or research.

- You may not further distribute the material or use it for any profit-making activity or commercial gain

If the publication is distributed under the terms of Article $25 \mathrm{fa}$ of the Dutch Copyright Act, indicated by the "Taverne" license above, 


\title{
Introduction: the politicisation of permanent crisis in Europe
}

\author{
Benedetta Voltolini (iD) ${ }^{a}$, Michal Natorski ${ }^{b}{ }^{b}$ and Colin Hay (iD ${ }^{c}$ \\ ${ }^{a}$ Department of European \& International Studies, King's College London, London, United Kingdom; \\ ${ }^{b}$ Maastricht Graduate School of Governance/UNU-MERIT, Maastricht University, Maastricht, the Netherlands; \\ 'Centre d'études européennes et politique comparée (CNRS), Sciences Po, Paris, France
}

\begin{abstract}
Taking stock of the numerous crises that have confronted Europe in the last decade, this special issue investigates the relationship between crisis and the politicisation of the process of European integration. It draws attention in so doing to the epistemic construction of crises. In this conceptual overview, we discuss first, how crises are framed and reframed in relation to the constitutive elements of a political community. Second, we explore the extent to which, and how, the emergence of different understandings of crisis and the ensuing frame competition between them contribute to such politicisation. By elucidating the link between the politics of a now seemingly permanent crisis in Europe and the politicisation of European integration, this introduction sets the framework informing all of the articles in this special issue.
\end{abstract}

\section{KEYWORDS}

Crises; politicisation; European integration; framing

\section{Introduction}

The idea that Europe is experiencing an exceptional and all-encompassing crisis (a crisis of crises even) has become widespread. The continent has indeed been confronted by a series of unprecedented events (perhaps most obviously, the Eurozone crisis, the 'ring of fire' in the neighbourhood, the Schengen crisis, Brexit and the rule of law crises in Poland and Hungary). Unremarkably perhaps this has led to the perception of an existential crisis of European integration that remains far from being resolved. While at times these crises have fostered European integration, in many cases they have also weakened the solidarity among European governments, societies and peoples, leading to a profound challenge to the European project and the threat of European integration giving way to European disintegration. In parallel to these numerous crises, the politicisation and public contestation of European integration have increased. European issues have acquired a new salience among European citizens and have mobilised polarised actors, who contest not only the decisions adopted in response to different crises but who also challenge the very roots of the European integration project.

Although some have assumed that politicisation has steadily increased over time, and especially in the post-Maastricht period (Hooghe and Marks 2009), others have linked periods of heightened politicisation with different ground-breaking events, such as new

CONTACT Benedetta Voltolini benedetta.voltolini@kcl.ac.uk Department of European \& International Studies, King's College London, 22 Kingsway, London, WC2B 6NR 
treaties and enlargement waves (Rauh 2018; Rauh and Zürn 2016; Hutter, Grande, and Kriesi 2016). Yet the role of crises as key (if not perhaps either necessary or sufficient) events in this evolving historical sequence still remains unclear (Zürn 2018). While Hutter and Kriesi (2019) demonstrate that the Euro and refugee crises represented critical junctures in the questioning of European integration, they also point to significant variations across macro-regions and crises. Others have argued that crises have contributed to the overall degree of politicisation of the EU by 'fracturing the cohesion of the Union's member states across new and changing cleavages', leading the EU into a politics trap (Zeitlin, Nicoli, and Laffan 2019, 963). Yet the precise relationship between multiple crises and politicisation in such accounts remains far from clear.

In this context, the current special issue aims to make two contributions to the existing literature. Analytically, it advances our understanding of how the politics of permanent crisis in Europe impact on the politicisation of the process of European integration. In a second move, it asks how the emerging patterns of politicisation shape the dynamics of crisis. This it does, above all, by exploring the epistemic dimension of crisis construction. We suggest that the struggle to frame certain events as symptomatic of a specific crisis (a crisis of $X$ or $Y$ ) serves to escalate or promote the level of politicisation. In other words, it is not the existence of something that might be referred to as a crisis in itself that leads to politicisation; rather, the way in which a crisis is framed and contested determines its potential impact on the level of politicisation of European integration. A political community becomes politicised (or not) around and in terms of the contested frames in and through which the crisis comes to be viewed, and ultimately lived. The contestation among different frames during a crisis can lead to the establishment of new cleavages beyond the immediate crisis circumstances and, in the long term, these frames of crisis can become naturalized in new forms, modes and repertoires of political conflict. On the one hand, crisis-generated politicisation can lead to a further entrenchment of the perception of an ongoing and unresolvable crisis in Europe, of European institutions and of the process of European integration itself. In this way, conflict-ridden feedback loops between crises, framing contests and politicisation can lead to increasingly disruptive policy cycles (most obviously where competing crisis frames persist). And these, in turn, threaten to precipitate a political disintegration of the European community itself. Yet, on the other hand, crisis-induced politicisation can stimulate further integration around newly redefined understandings of core aspects of European political community when there are constructive (typically convergent) feedback loops between crises, framing contests and politicisation.

This special issue gathers together a series of innovative empirical studies that cover a wide range of policies from a variety of methodological perspectives. It thus offers the possibility of cross-policy and cross-methods comparison across different policy domains. We seek to provide a balanced view of the different types of crises that the EU has been facing over the past decade, including articles on the migration crisis (Castelli and Zamponi 2020; Hadj-Abdou 2020), the Eurozone crisis (Kutter 2020; Moreira Ramalho 2020), identity and/or culture crises (Coutto 2020; Ganesh and Froio 2020; Voltolini 2020), and external crises (Natorski 2020; Voltolini 2020; Ikani 2020). This broad empirical and methodological reach, we hope, adds to the existing literature which to date has focused predominantly on the Eurozone and the refugee crises. 
This introductory essay proceeds as follows. First, it surveys the existing literature on crises and politicisation in Europe, questioning current accounts of the relations between crises and politicisation. Second, it develops the analytical framework of this special issue to investigate the epistemic dimension of the crisis, drawing out its implications for the process of politicisation. It focuses on two dimensions: (i) how crises are constructed by actors, i.e. the way in which events and issues come to be portrayed as symptomatic of a specific crisis type; (ii) the process of symbolic contestation and epistemic competition between different frames in this process of crisis definition. Finally, by discussing how the articles in this special issue engage with these two aspects, this section highlights how and to what extent the process of European integration is politicised in times of crises. In a short conclusion, we outline the implications of this politicisation on the production of a sense of permanent crisis in Europe.

\section{European integration between crises and politicisation}

The numerous internal and external shocks faced by the European Union over the past decade have inspired a new wave of literature on EU integration in turbulent times. Since 2008 there have been prolific debates on the origins, the institutional trajectories and dynamics of decision-making as well as consequences of the multiple European crises on the EU integration. Despite the richness and intensity of such exchanges, this literature remains unclear about the causal role of crises and even the very definition of the term.

In most of this literature, crises have been considered as critical junctures and triggers of specific policy and institutional innovation. Change in policy design, policy-making procedures and bouts of institutional creation has all been attributed to crises (typically construed as 'external shocks'). Yet, the extent of such ostensibly crisis-engendered chance clearly varies greatly between crises and, indeed, policy areas (Kratochvíl and Sychra 2019; Höing and Kunstein 2019; Burns, Clifton, and Quaglia 2017; Biermann et al. 2017). For example, whilst the Eurozone crisis fostered further integration in the economic domain, the refugee crisis has deepened the already existing divisions among member states, leading to the paralysis of the EU. Variations in outcomes are thus not directly caused by crises, but are, in most instances, mediated by other domestic and international factors such as intra-European cleavages among member states during Eurozone crisis, as well as the prominence of populist parties and the degree of involvement of third actors, such as Turkey, during the refugee crisis.

Perhaps more problematically still, there remains much conceptual vagueness in the use of the term 'crisis' and little theoretical depth concerning the nature of crises and their relation to processes such as politicisation. Leading authors have acknowledged that the simultaneous presence of multiple EU crises challenges traditional European integration theories (for instance, Saurugger 2016; Börzel and Risse 2018; Schimmelfennig 2018b). But it remains unclear how different and specific crises have contributed to the generation of different and specific outcomes. Many influential accounts simply reinforce an argument about the inherently conflictual and political character of European integration given the diversity of values, preferences and interests among European actors. They do so because they present crises as the product of other theoretical concepts (bargaining, conflicts) rather than as having any independent influence (Hooghe and Marks 2019). Our aim is to correct that oversight. 
But that is no simple task. For how crises contribute to politicisation is itself still to be settled. Politicisation is generally conceived as a process by which issues move from the non-political realm (that of fate and/or necessity) to the political realm (that of contingency and deliberation) (Hay 2007, 78-82, 2014). Issues are politicised when they 'become the subject of deliberation, decision-making and human agency where previously they were not' (p. 81) and they can then further move up to the level of government deliberation when they become a part of a more formal legislative process. As Hay suggests, issues can thus move from the non-political to the political spheres and be more or less politicised, depending on the sphere of the political in which they are debated, contested and dealt with. The movement (or promotion) of an issue into a realm of consciously political deliberation and decision-making often entails 'the expansion of the scope of conflict within the political system' (Grande and Hutter 2016, 7).

As Zürn (2018) suggests,

(Non)-decisions, decision-making processes, or the institutions that make decisions are politicised if the awareness (of individuals), social mobilization (of social groups) and public debates (in the mass media) indicate that they are seen as being in the realm of public choice. If something is politicised, one should see increasing salience of the matter, a broader participation, and increased contestation about it.

Politicisation is then typically characterised by an increase in issue salience, the expansion of the range of actors expressing a stake in the issue and an associated polarisation of the positions actors adopt with respect to the issue (de Wilde 2011; de Wilde, Leupold, and Schmidtke 2016; de Wilde and Zürn 2012; Börzel and Risse 2018; Hutter and Kerscher 2014; Hutter, Grande, and Kriesi 2016). The process of European integration itself thus become politicised when there is a 'more publicly visible contestation related to the various dimensions of European integration' (Hutter and Kriesi 2019, 997).

This politicisation is in turn likely to relate to the most fundamental features of a community, such as its boundaries, authority, sense of belonging and justice, identity and institutions. For example, Hooghe and Marks (2009) and Börzel and Risse (2018) argue that identity-related issues are particularly prone both to stimulate and be stimulated by the politicisation of European affairs (Maricut-Akbik 2018). Issues of solidarity and belonging are also raised by de Wilde and Zürn (2012), who suggest that an increase in politicisation is associated with the transfer of authority from national to European actors. Similarly, Hurrelmann, Gora, and Wagner (2013) maintain that the costs and benefits of EU membership and the legitimacy of constitutional arrangements, rather than day-to-day activities, predominantly affect the politicisation of European integration.

Others have added to this discussion of politicisation by looking at its different manifestations across EU institutions, decision-making processes and issues (de Wilde 2011), as well as its mechanisms, causes and structuring potential (Statham and Trenz 2014). Furthermore, and most importantly, different positions on the effects of politicisation on European integration have been highlighted in the literature. For some, politicisation can constrain integration (Hooghe and Marks 2009), enhance differentiation among member states across policy areas (Schimmelfennig, Leuffen, and Rittberger 2015) and lead to a multi-level politics trap (Zeitlin, Nicoli, and Laffan 2019). Yet others see it as enhancing EU legitimacy (Schmitter 1969).

The political nature of conflict about EU integration has been exposed during multiple crises, as manifested in the intense mobilization and polarization of actors in relation to 
the constitutive features of these critical events. Hutter, Grande, and Kriesi $(2016,280)$ argue that significant variations in the patterns of politicisation can be identified over time, across countries and political arenas, to the point that it seems more appropriate to speak of a process of 'punctuated politicisation', in which certain events produce strong political contestation for short periods of time. In this context, many authors assume that critical events such as crises can punctuate politicisation trends. But there is no agreement about the exact nature of this relationship. Hutter and Kerscher (2014) emphasise that whilst the Eurozone crisis boosted politicisation at the level of national electoral politics, it did not change the way in which 'conflicts over Europe are fought' (p. 280). However, they also note that the link between politicisation and crisis remains under-researched. Kriesi (2016) suggests that the politicising impact of the Eurozone crisis led to the mobilisation of pre-existing but tacit region- and/or nation-specific cleavages. Finally, Leupold (2016) suggests that crisis-induced politicisation is different from other forms of politicised since it typically induces polarization between states rather than within states.

While crises can be considered as one of the factors providing conditions for politicisation, their role is in fact highly contingent - not least on processes of framing. Crisis can drive European integration when nation-states are seen as incapable of preventing or successfully managing crises. On the other hand, crises can lead to a situation of perceived paralysis. For example, Zeitlin, Nicoli, and Laffan (2019) suggest that the poly-crisis of the EU generates multiple and simultaneous cleavages that often lead to policy and institutional deadlock. At the same time, however, crises 'may be used to accentuate failures of the EU rather than failures of the independent nation-states and they may prompt demands for fewer European solutions rather than more' (de Wilde and Zürn 2012, 145). Therefore, crises can contribute to politicising European affairs in the national arenas rather than at the supranational level (Baglioni and Hurrelmann 2015; Wonka 2015). Castelli and Zamponi's article (2020) is indicative of this kind of process. It shows how European policies concerning migration and asylum have been politicised in the French context, leading to direct action at the national level. These opposing outcomes of crises, both fostering and halting integration, are well illustrated by Börzel and Risse (2018), who argue that politicisation can lead either to further pooling of authority or to the constraining of existing integrated policies, depending on what segments of collective identities are mobilized. Crisis definitions, in this sense, become political resources which may serve to empower either domestic or European-level actors depending on who proves most adept in crisis framing. And, as this in turn suggests, the link between a crisis and the political action to which it gives rise is contingent upon crisis framing.

In light of this prolific, yet ultimately contradictory, literature on the relationships between European crises and politicisation, we argue that these numerous crises in Europe have unfolded in the context of an already increasing politicisation of European integration and that the two processes need to be seen as analytical distinct if increasingly inter-connected. To unpack the link between crises and politicisation of European integration, this special issue sheds light on the epistemic dimension of crises. By this, we mean the political process in and through which certain events come to be framed as constitutive of a moment (of crisis) that requires a decisive intervention (Hay 1999). Our concern is with how such framing contributes to the politicisation (or, indeed, depoliticisation) of the process of European integration. That focus requires us to tackle two inter-related sub-questions that inform the contributions to this special issue. The first is how crisis are framed (and potentially re-framed) and how, in the 
process, they might serve to politicise European integration. Here we draw on the literature on crises and their narrated construction. The second is how and why a single crisis frame has become dominant in shaping European integration dynamics. Here we consider more directly the literature on framing, exploring the competition between different accounts of crises and their potential for politicisation.

\section{The framing of crises and politicisation}

Because politicisation is, at heart, a discursive process, this special issue argues that the ways in which specific events are framed as crises and, more precisely, as specific types of crises have an impact - directly or indirectly - on the understanding of European and national communities. The framing of crises can indeed deal with ideas of belonging, boundary, and identity and/or with the dynamics of redistribution, solidarity, sovereignty, democratic legitimacy, participation, and institutions that define and shape authority in the community. When the way crises are framed and/or re-framed questions the dominant understandings of the essential features that are constitutive of a community, then European integration can itself potentially become the subject of politicisation.

Framing consists of 'promot[ing] a particular problem definition, causal interpretation, moral evaluation and/or treatment recommendation. [...] Frames diagnose, evaluate and prescribe' (Entman 1993, 52). As Snow and Benford (1988) suggest, frames have a diagnostic (identification of the problem and attribution of blame), a prognostic (solution to the problem, strategies and tactics) and a motivational (rationale for action) component. Hence, through framing processes, actors establish relationships of cause and effect, means and ends, right and wrong, good and bad, etc. It is these which become the basis of the interpretation of events, providing as they do ways of organising facts, beliefs and perceptions (Bardwell 1991; Huber 1991). By making problems amenable to interpretation, frames guide action and shape policy responses (Weiss 1989; Gusfield 1981; Hay 1996; Voltolini 2016).

While framing is one of the key aspects of politicisation, frames matter to different degrees. As de Wilde et al. $(2016,16)$ suggest, 'processes of sense-making and framing are likely to impact on the nature of politicisation. They may well facilitate or inhibit politicisation and carry implications for the consequences of politicisation'. Similarly, as Hutter, Grande, and Kriesi (2016) show, not all frames have the same polarizing effects.

Frames are (at least partially) deployed strategically by agents involved in a struggle over the definition and re-definition of the constitutive features of the EU community. Making sense of crises is normally characterized by a competition among different frames, leading to dynamics of contestation to impose one narrative over another. Not only are some actors more capable than others of framing and thereby constructing authoritative crisis narratives but the very definition of events as a crisis also empowers certain actors over others and changes power relations in political systems (Hay 2016). The analysis of the power dynamics in the European community underlying the process of framing implies the study of different European, transnational and national actors engaged in frame competition, the resources they mobilize, and the mechanisms that make certain frames durable and dominant.

In addition to the strategies and resources mobilised by actors, framing takes place in the multi-level governance system of European integration. de Wilde and Zürn (2012) 
suggest that mediating institutional and discursive opportunity structures define separately the dynamics of politicisation. In their account, institutional opportunity structures are constituted by external shocks, party competition at the national level and major treaty negotiations at the European level. Discursive opportunities encompass 'dominant narrative of European integration in different countries - that is, the different incorporation of the EU into the political self-perception of a national community' as well as media attention for EU issues (de Wilde and Zürn 2012, 141). Yet, in contrast to other contributions focussed on the discursive construction of crisis, they overlook the possible interaction effects between these two dimensions. Similarly, Hurrelmann, Gora, and Wagner (2013) argue that politicisation takes place in different institutional discursive arenas, yet the interactions across them remain unexplored.

In what follows, we consider the two guiding questions of this special issue, detailing our shared analytical framework and highlighting how the different contributions that follow engage with and build upon it.

\section{The narrated construction of crises}

Contrary to a number of accounts that conceive of crises as simply external and exogenous shocks (for instance, Schimmelfennig 2018a), this special issue unpacks the constructed and discursive nature of crises (Hart 1993; Hay 1996, 1999; Widmaier 2007; Davis Cross 2017) - in effect, it seeks to endogenise crises within an overall analysis of institutional change (Hay 2016). Crises have material bases, but it is their perception, interpretation and discursive construction by actors that make an event recognisable as a crisis (and, indeed, as a crisis of a particular kind). All crises are lived experiences, mediated through language and cognition. Unexpected events do not speak for themselves; they possess an inherent 'interpretive ambiguity' ('is this a crisis?', 'of what is this a crisis?', 'what would be a condition of its resolution?'); their critical character is perceived by affected actors (Brecher 2008, 9); and is expressed in narratives (Hay 1999, 2016; Widmaier 2007).

Therefore, the process of identifying an event as a crisis and of making sense of it in such terms involves narrating its origins, causes, incidences, developments, scope, effects and prospective solutions in space-time horizons. It also entails implicating agents at different levels of the relevant social hierarchies (Jessop 2015, 249). Each can be seen as the (partial) resolution of an interpretive ambiguity in that a set of symptoms capable of being viewed as a crisis can be viewed in a variety of rather different ways (Hay 2016). Crisis definition and framing are about establishing a way of viewing a set of events - as a crisis and as a crisis of a particular kind. A crisis denotes an unexpected occurrence that disrupts the normal functioning of socio-political structures, threatening core social values and the political-institutional order of a community (Boin, Hart, and McConnell 2009, 83-4; Boin, Ekengren, and Rhinard 2013, 6; Davis Cross 2017).

As suggested by Boin, Bengt, and Stern (2005), crises occur when there is the perception that the core values of a community are under threat, there is a strong sense of urgency and time pressure which is combined with a growing sense of uncertainty. Ganesh and Froio (2020), for example, show how the far-right's narrative revolves around the perception of a cultural crisis, which challenges the core identity of Europe. Another form of identity crisis is also discussed by Voltolini (2020), who suggests that the 
challenges to the core traits of EU external identity created a situation of urgency and the need to react by ensuring that the EU's raison d'être and its foreign policies were aligned. By narrating events and policies in terms of the defining features of EU identity, non-state actors have thus a strong potential to politicise EU external relations. In a similar way, Coutto (2020) maps the frames in and through which both the official and unofficial Brexit campaigns sought to seize the short window of opportunity opened by the referendum of Britain's continued EU membership to argue for a decisive intervention to sever once and for all that relationship, overturning in the process a long-standing relationship of domination and dependency.

Crises thus contribute to the 'spectacularization of failure' (Moffitt 2016, 17): with identified failure(s) thus providing the structural basis and pre-condition of crisis narration. But a moment only becomes a crisis if such identified failures come to be widely perceived as symptomatic of a wider problem. As such, the promotion of failure into crisis is both 'politically and ideationally mediated' (Hay 1999, 324). How events and issues are framed is thus decisive not only in terms of whether and how crises are perceived and defined but also crucially how they come to be addressed and responded to (Blyth 2007; Hay 2016). This is evident in the case of the migration crisis of 2015 detailed by Castelli and Zamponi (2020) and Hadj-Abdou (2020). The former argues that in the French context the crisis was identified at the level of policy response, i.e. an inadequacy by local, national and supranational governmental actors to address exceptional migration flows. This, in turn, led to the polarization of collective actors on the basis of their diametrically opposed preferences and views of the phenomenon. While the solidarity movement employed direct actions to concretely help migrants and increase the visibility of the problem, the anti-immigration movement used direct activism to set the agenda and present migration as a security issue. In contrast, the latter suggests that migration was caused by both the liberal policies of Western states and, additionally, by the smugglers that made the crossing possible. Hence, deterrence was perceived as the only credible response to the challenge of increasing migratory flux.

Whilst a crisis narrative conjures the need for a moment of decisive intervention, exposing the contradictions of the past and establishing their role in the failure(s) of the present (Hay 1999), crisis narratives are also prospective in that they impose parameters on the type of intervention required to redress such failures (Roitman 2013). For example, Laffan (2014) demonstrates that, by portraying the Eurozone crisis as one of the fiscal profligacy of peripheral member states, the only credible solution became austerity (see also Hay 2013). Such a reading or construction of events, in other words, has drawn attention away from other initially no less credible responses, such as those seeking to redress the adequacy of banking regulation and/or the asset-bubble inflating investment algorithms of institutional investors. Moreira Ramalho (2020) reaches similar conclusions. It shows that, by narrating the Eurozone crisis as the result of domestic failures and moral hazard, the Troika paved the way for austerity as the only possible option. The relevance of framing of the Eurozone crisis is also central in Kutter's article (2020), which shows that the dominant narrative identified fiscal mismanagement, missing competitiveness, macroeconomic imbalances and EMU design as the causes of the sovereign debt crises and recession. The dominant crisis construction, in other words, necessitated fiscal consolidation and structural reform. Similarly, Natorski (2020) illustrates how in the light of 
the crisis in Ukraine the continuity of frames defining the situation in the EU neighbourhood constrained the politicization of the crisis response.

Brändström and Kuipers $(2003,280)$ suggest that the politicisation of events happens when these are framed as 'blameworthy violations of crucial public values'. In their view, there are three steps linking political failures and politicisation. First, the severity of events needs to be established in terms of the violation of core values of the political system. Once events are perceived as crises, then there is a political and societal debate and the politics of blaming can take place. Second, the causes and agency of the crisis have to be identified, distinguishing between one-time occurrences and more profound long term and underlying causes. Finally, blame needs to be attributed so that action can be taken. This link between framing, naming, blaming and politicisation is clear in the case of the Eurozone crisis discussed by Moreira Ramalho (2020). While the Troika's discourse is also a response to the different levels of politicisation across time and countries, blame was firmly focused on the southern EU member states and their policies of moral hazard.

Yet, as Hutter et al. note, 'frames are not all polarising to the same extent' $(2016,291)$. This means that politicisation is not a given or inevitable outcome. It is how the core features of a political community are mobilised in these framing processes that are ultimately responsible for the degree of politicisation achieved. It is how a crisis is perceived and narrated that determines the impact on the process of European integration. For example, Börzel and Risse (2018) suggest that, while the debate on the Euro crisis was framed in terms of European political and economic order - and was depoliticised the Schengen crisis was framed, especially by right-wing parties, in terms of exclusionary collective identity, i.e. us vs. them. This too is precisely the discourse of the Brexiteers, as is shown in Coutto's article (2020). With respect to Schengen, it became impossible for politicians to depoliticise this crisis through supranational delegation; and with respect to Brexit, for the Brexiteers at least, leaving the EU was the triumph of 'us', the sovereign domestic people, over 'them', the faceless bureaucrats of Brussels. This idea of the conflict of 'us' vs. 'them' is also central to Ganesh and Froio's (2020) contribution. It shows how farright actors use Twitter to promote the narrative of a cultural crisis of Europe based on a nativist reading of current events (notably the migration and economic 'crises').

Yet while identity crises have strong politicising potential, there is no automatic causal relation. Voltolini (2020) demonstrates that whether an 'ontological crisis' leads to politicisation strongly depends on which identity features are mobilized and which strategies external actors use to push for policy change. The politicisation potential of a crisis is, in this case, dependent on the lobbying strategies adopted. These can either aim at making an issue public or at keeping it confined to the institutional arena. Again, we come back to crisis narratives as weapons or resources in political conflict.

\section{Frame competition and dominance}

As discussed above, frames result from - and are the direct product of - processes of social construction. This means that a variety of actors participate in their definition and codification. The presence of different actors also implies that different interpretations and narratives compete in the process of framing. Each stakeholder tries to propose their interpretation of events: this leads to the dynamics of competition and contestation among initially diverging understandings. The differences and competition between 
different frames of crisis can thus open the space for politicisation by polarizing positions and raising the salience of the issue at stake.

In and through this competition, there is usually a point at which one frame becomes dominant - and, in the process, the privileged guide to subsequent policy-making. But crucially not only are some actors more capable than others of framing and constructing understandings of crisis, the very definition of an event as a crisis also empowers certain actors over others. The analysis of the power dynamics in the European community underlying the process of framing thus requires the study of different European, transnational and national actors engaged in frame competition, the resources they mobilize, and the mechanisms that make certain frames durable authoritative and dominant (Warren 2017).

Under normal circumstances, one frame tends to dominate, leaving little space for counter-narratives and alternative understandings. However, when the existing frame starts to be perceived as inadequate to make sense of a set of events and circumstances, then it is more likely that new (initially dissident or heterodox) frames emerge and are deployed in the attempt to supplant the dominant frame. This can take place via processes of reframing (Laws and Rein 2003), which refers to the erosion to the dominant frame coming 'from within'. When confronted with new facts and events, actors need to reassess and reevaluate their beliefs. This process may lead to a gradual and progressive cognitive evolution that can, over time, bring about significant change - even a paradigm shift.

Thus, understanding the competition that underlies the framing process helps us to shed light on power dynamics as well as to unpack the implications that the dominance of one frame over others has in terms of the politicisation of the European integration process and the enduring sense of crisis in Europe. This is the case as frames tend to become institutionalised and embodied in practices, i.e. they become taken-for-granted assumptions that provide the basis for routinized and spontaneous action by actors. This way, frames become enduring, tangible and more difficult to set aside (cf. Schoen and Rein 1994; Laws and Rein 2003). As in the case of the crisis in Ukraine analysed by Natorski (2020), when EU institutions actively employ existing frames, they both avoid the politicisation of the issue and protect their status in EU foreign policy.

The framing of crises is, like any framing process, a profoundly 'political act' (Abolafia 2004). Frame contest becomes particularly evident when unstable circumstances occur, as these force actors to make sense of the situation and might open windows of opportunity for new frames to become dominant. Calling something a crisis does in itself create opportunities for frame competition and, above all, for a change of the dominant frame. Key factors that have been used to explain frame contests (cf. Kaplan 2008) are resonance, legitimacy and frame realignment. It is indeed central for a frame to resonate with 'audiences' previous beliefs, worldviews and life experiences' (Williams 2004, 105) as well as with the empirical context of the targeted audience (Joachim 2003). Frame proponents thus try to increase the empirical credibility (evidence and empirical support for a claim), its experiential commensurability (the extent to which actors are directly affected) and its ideational centrality (striking a responsive chord of already existing beliefs and myths) (Snow and Benford 1992). Moreover, Benford and Snow (2000) argue that actors engage in legitimacy battles to strengthen their authority as claim-makers and have thus the right to impose their frame as the dominant narrative. At the same time, they try to bridge and combine unconnected frames and aligning them to new 
circumstances (Snow et al. 1986). In so doing, actors attempt at mobilising other stakeholders and building coalitions to impose around certain frames.

The presence of a dominant frame is evident in Ganesh's and Froio's (2020) article. The authors convincingly argue that the cultural lens overtakes all other possible readings and becomes the umbrella term for understanding all crises (a meta-frame in effect). For farright leaders and activists, this encompassing frame explains all the problems Europe is facing today and provides a straightforward policy answer. Here the emotional chord that this frame strikes has thus mobilizing potential. Similarly, Moreira Ramalho (2020) demonstrates that the Troika managed to impose its reading based on moral hazard and austerity to legitimise and justify its policies at the European level. The fragmentation highlighted by Zamponi and Bosi (2016) in the public discourse on the crisis across European countries is possibly the reason why alternative narratives did not manage to challenge the Troika's frame to a significant degree. As Kutter (2020) suggests, there was a counter-narrative of a social and political crisis due to EU austerity policies, with debt cancellation and joint stimulus programmes as solutions. Yet, these attempts at politicisation were countered by the depoliticisation strategies mobilised by supporters of the dominant frame, who co-opted and tied the idea of growth to supply-side policies, such as deregulation. In a similar way, as Coutto (2020) shows, Brexit becomes a master frame for Brexiteers - a focus for any and all opposition, of whatever kind, to the process and perceived consequences of European integration.

In the case of migration, Hadj-Abdou (2020) shows that the dominant narrative at the European and American governmental level legitimises a pre-crisis policy of deterrence of migratory flows. While consensus on the role of pull and push factors in determining the migration crisis of 2015 is widespread among governmental actors, civil society holds opposing views, as Castelli and Zamponi (2020) demonstrate. The polarization and mobilization take place at the street level, where a similar frame of the crisis (policy inadequacy) gives rise to different forms of direct activism from social movements. The dominant frame at the institutional level is hence challenged in the citizens' arena.

In the foreign policy domain, Ikani (2020) shows how crises can challenge existing institutional frames and arrangements, as issues gain salience and become contested. Yet, whether new crisis frames manage to replace old narratives is mediated and shaped by historical institutional arrangements which affect the actors' efforts to negotiate changes. In the case of the ENP, new frames floated as a consequence of the Arab uprisings and the Ukrainian crisis, but their success at supplanting entrenched policies was strongly constrained by the institutional context. In contrast, Voltolini (2020) discusses the emergence of frames proposed by non-state actors to challenge existing EU policies and countermoves by alternative coalitions of actors to induce further change. While some frames might be better able to shape EU policies because of the inherent features of the narrative proposed (empirical credibility), there are continuous attempts at weakening this dominance by proposing alternative readings that strike emotional chords.

\section{Conclusions}

What is clear is that the process of European integration is more challenged and contested today than it has ever been. Europe faces and, above all, is seen to face a series of challenges of an almost existential kind (see also Hay 2020). That condition, seen 
collectively, represents - or might be seen to represent - a crisis of European integration and of the conception of European identity that has evolved to sustain it over several decades. Whether Europe and European institutions will survive that challenge remains an open empirical question. But what is clear, as the various contributions to this special issue show, is that the framing and re-framing of crises - and of the European crisis itself will be crucial to that.

But it is important to remember that crises involve a double framing. The first level of framing involves the identification of a situation as one of the crisis in the first place. This already achieves a certain politicisation - for it raises the political stakes of the moment in question, elevating it from the normal 'failure' to exceptional 'crisis'. Crises require different and exceptional interventions for their resolution and the stakes of such political interventions are very high indeed, challenging as they do potentially all prevailing relevant orthodoxies.

But crises also involve a second level of framing. This relates not to the existence of the crisis, but to the nature and character of the crisis - of what is this a crisis? This, too, is crucial. A crisis of debt is not a crisis of growth (Hay 2013), and whilst the global crash of 2008 and the Eurozone crisis to which it led might credibly be seen in either terms, it is clear that austerity is an appropriate response to a crisis of debt but a very far from appropriate response to a crisis of growth. Framing a crisis as a crisis of $X$ or $Y$ is, then, a far from an innocent and apolitical choice. It, too, is integral to the politics of crisis definition. For is it only by coming to see a situation as both a crisis and a crisis of a particular kind that we come to see the strategies and responses appropriate to its resolution. Change our identification or framing of the crisis and we change fundamentally the nature of the response required to address it.

That brings us to a final issue. The sub-title of this special issue contains within it a paradox of a deliberate kind. For crises, understood in and through the ancient (Greek) etymology of the term, are moments of decisive intervention - and, as such, they cannot be permanent (Hay 1999). They represent, in effect, a quickening of the pace and the pulse of political time; a moment in which the old gives way to the new through an intervention of a decisive and, in this case, institution- and identity-shaping kind.

Europe today faces such a moment. Its seemingly permanent crisis cannot endure indefinitely. To return again to the Greek etymology of the term and the analogy of medical practice with which it has come intimately to be associated, the moment of crisis is the moment in the life course of the patient in which the doctor's decisive intervention would determine whether the patient would live or die.

Yet there is one key difference between this venerable ancient medical analogy and Europe's present political predicament. It is that political crises, as we have argued, are manufactured and narrated. As such, the patient has at least a hand in whether she lives or dies. It remains to be seen whether the European patient will choose to conjure the collectively decisive intervention required to bring about her recovery or whether her condition will, indeed, prove terminal.

\section{Acknowledgments}

The authors would like to thank the anonymous reviewers for their helpful comments on an earlier version of this manuscript. Benedetta Voltolini would also like to thank the Centre d'études européennes et politique comparée of Sciences Po for the support in the organization of the 
workshop 'The framing of crisis in Europe' in December 2017, organised within the framework of the Marie Skłodowska-Curie grant agreement No. 657949.

\section{Disclosure statement}

No potential conflict of interest was reported by the authors.

\section{Funding}

This work was supported by the European Union's Horizon 2020 research and innovation programme under the Marie Skłodowska-Curie grant agreement [No. 657949].

\section{ORCID}

Benedetta Voltolini (D) http://orcid.org/0000-0002-4212-5528

Michal Natorski (iD http://orcid.org/0000-0002-2736-1709

Colin Hay (D) http://orcid.org/0000-0001-6327-6547

\section{References}

Abolafia, M. Y. 2004. "Framing Moves: Interpretive Politics at the Federal Reserve." Journal of Public Administration Research and Theory 14 (3): 349-370. doi:10.1093/jopart/muh023.

Baglioni, S., and A. Hurrelmann. 2015. "The Eurozone Crisis and Citizen Engagement in EU Affairs." West European Politics 39 (1): 104-124. doi:10.1080/01402382.2015.1081507.

Bardwell, L. V. 1991. "Problem-Framing: A Perspective on Environmental Problem-Solving." Environmental Management 15 (5): 603-612. doi:10.1007/BF02589620.

Benford, R. D., and D. A. Snow. 2000. "Framing Processes and Social Movements: An Overview and Assessment." Annual Review of Sociology 26: 611-639. doi:10.1146/annurev.soc.26.1.611.

Biermann, F., N. Guérin, S. Jagdhuber, B. Rittberger, and M. Weiss. 2017. "Political (Non-)reform in the Euro Crisis and the Refugee Crisis: A Liberal Intergovernmentalist Explanation." Journal of European Public Policy 26 (2): 246-266. doi:10.1080/13501763.2017.1408670.

Blyth, M. 2007. "Powering, Puzzling, or Persuading? The Mechanisms of Building Institutional Orders." International Studies Quarterly 51 (4): 761-777. doi:10.1111/j.1468-2478.2007.00475.x.

Boin, A., M. Ekengren, and M. Rhinard. 2013. The European Union as Crisis Manager. Patterns and Prospects. Cambridge: Cambridge University Press.

Boin, A., P. T. Hart, and A. McConnell. 2009. "Crisis Exploitation: Political and Policy Impacts of Framing Contests." Journal of European Public Policy 16 (1): 81-106. doi:10.1080/ 13501760802453221.

Boin, A., S. Bengt, and E. Stern. 2005. The Politics of Crisis Management: Public Leadership under Pressure. Cambridge/New York: Cambridge University Press.

Börzel, T. A., and T. Risse. 2018. "From the Euro to the Schengen Crises: European Integration Theories, Politicization, and Identity Politics." Journal of European Public Policy 25 (1): 83-108. doi:10.1080/13501763.2017.1310281.

Brändström, A., and S. Kuipers. 2003. "From "Normal Incidents" to Political Crises: Understanding the Selective Politicization of Policy Failures1'." Government and Opposition 38 (3): 279-305. doi:10.1111/1477-7053.t01-1-00016.

Brecher, M. 2008. International Political Earthquakes. Ann Arbor: University of Michigan Press.

Burns, C., J. Clifton, and L. Quaglia. 2017. "Explaining Policy Change in the EU: Financial Reform after the Crisis." Journal of European Public Policy 25 (5): 728-746. doi:10.1080/ 13501763.2017.1301535. 
Castelli, P., and L. Zamponi. 2020. “Politicizing Support and Opposition to Migration in France: The EU Asylum Policy Crisis and Direct Social Activism." Journal of European Integration 42 (5): 625-641.

Coutto, T. 2020. "Half-full or Half-empty? Framing of UK-EU Relations during the Brexit Referendum Campaign." Journal of European Integration 42 (5): 695-713.

Davis Cross, M. K. 2017. The Politics of Crisis in Europe. Cambridge/New York: Cambridge University Press.

de Wilde, P. 2011. "Polity for Old Politics? A Framework for Analyzing the Politicization of European Integration.'." Journal of European Integration 33 (5): 559-575. doi:10.1080/07036337.2010.546849.

de Wilde, P., A. Leupold, and H. Schmidtke. 2016. "Introduction: the differentiated politicisation of European governance". West European Politics 39(1): 3-22. doi:10.1080/01402382.2015.1081505

de Wilde, P., and M. Zürn. 2012. "Can the Politicization of European Integration Be Reversed?" Journal of Common Market Studies 50 (S1): 137-153. doi:10.1080/01402382.2016.1184415.

Entman, R. M. 1993. "Framing: Toward Clarification of a Fractured Paradigm." Journal of Communication 43 (4): 51-58. doi:10.1111/j.1460-2466.1993.tb01304.x.

Ganesh, B., and C. Froio. 2020. "A "Europe Des Nations": Far Right Imaginative Geographies and the Politicization of Cultural Crisis on Twitter in Western Europe." Journal of European Integration 42 (5): 715-732.

Grande, E., and S. Hutter. 2016. "Introduction. European Integration and the Challenge of Politicisation." In Politicising Europe: Integration and Mass Politics, edited by S. Hutter, E. Grande, and H. Kriesi, 3-31. London/New York: Cambridge University Press.

Gusfield, J. R. 1981. The Culture of Public Problems. Drinking-Driving and the Symbolic Order. Chicago and London: University of Chicago Press.

Hadj-Abdou, L. 2020. "Push or Pull'? Framing Immigration in Times of Crisis in the European Union and the United States." Journal of European Integration 42 (5): 695-713.

Hart, P. T. 1993. "Symbols, Rituals and Power: The Lost Dimensions of Crisis Management." Journal of Contingencies and Crisis Management 1 (1): 36-50. doi:10.1111/j.1468-5973.1993.tb00005.x.

Hay, C. 1996. "Narrating Crisis: The Discursive Construction of the "Winter of Discontent"." Sociology 30 (2): 53-77. doi:10.1177/0038038596030002004.

Hay, C. 1999. "Crisis and the Structural Transformation of the State: Interrogating the Process of Change." British Journal of Politics and International Relations 1 (3): 317-344. doi:10.1111/1467856X.00018.

Hay, C. 2007. Why We Hate Politics. Cambridge: Polity Press.

Hay, C. 2013. The Failure of Anglo-Liberal Capitalism. Basingstoke: Palgrave Macmillan.

Hay, C. 2014. "Depoliticisation as Process, Governance as Practice: What Did the 'First Wave' Get Wrong and Do We Need a 'Second Wave' to Put It Right?" Policy \& Politics 42 (2): 293-311. doi:10.1332/030557314X13959960668217.

Hay, C. 2016. "Good in a Crisis: The Ontological Institutionalism of Social Constructivism." New Political Economy 21 (6): 520-535. doi:10.1080/13563467.2016.1158800.

Hay, C. 2020. "Brexistential Angst and the Paradoxes of Populism: On the Contingency, Predictability and Intelligibility of Seismic Shifts." Political Studies 68 (1): 187-206. doi:10.1177/ 0032321719836356.

Höing, O., and T. Kunstein. 2019. "Political Science and the Eurozone Crisis. A Review of Scientific Journal Articles 2004-15." JCMS: Journal of Common Market Studies 57 (2): 298-316.

Hooghe, L., and G. Marks. 2009. "A Postfunctionalist Theory of European Integration: From Permissive Consensus to Constraining Dissensus." British Journal of Political Science 39 (1): 1-23. doi:10.1017/S0007123408000409.

Hooghe, L., and G. Marks. 2019. "Grand Theories of European Integration in the Twenty-first Century." Journal of European Public Policy 26:8, 1113-1133.

Huber, G. P. 1991. "Organizational Learning: The Contributing Processes and the Literatures." Organization Science 2 (1): 88-115. doi:10.1287/orsc.2.1.88.

Hurrelmann, A., A. Gora, and A. Wagner. 2013. "The Politicization of European Integration: More than an Elite Affair?" Political Studies 63 (1): 43-59. doi:10.1111/1467-9248.12090. 
Hutter, S., and A. Kerscher. 2014. "Politicizing Europe in Hard Times: Conflicts over Europe in France in a Long-term Perspective, 1974-2012." Journal of European Integration 36 (3): 267-282. doi:10.1080/07036337.2014.885752.

Hutter, S., E. Grande, and H. Kriesi, eds. 2016. Politicising Europe. Integration and Mass Politics. London/New York: Cambridge University Press.

Hutter, S., and H. Kriesi. 2019. "Politicizing Europe in Times of Crisis." Journal of European Public Policy 26 (7): 996-1017. doi:10.1080/13501763.2019.1619801.

Ikani, N. 2020. "European Foreign Policy in Times of Crisis: A Political Development Lens." Journal of European Integration 42 (5): 715-732.

Jessop, B. 2015. "Crises, Crisis-management and State Restructuring: What Future for the State?" Policy and Politics 43 (4): 475-492. doi:10.1332/030557314X14156337971988.

Joachim, J. 2003. "Framing Issues and Seizing Opportunities: The UN, NGOs, and Women's Rights." International Studies Quarterly 47: 247-274. doi:10.1111/1468-2478.4702005.

Kaplan, S. 2008. "Framing Contests: Strategy Making under Uncertainty." Organization Science 19 (5): 729-752. doi:10.1287/orsc.1070.0340.

Kratochvíl, P., and Z. Sychra. 2019. "The End of Democracy in the EU? The Eurozone Crisis and the EU's Democratic Deficit." Journal of European Integration 41 (2): 169-185. doi:10.1080/ 07036337.2019.1569001.

Kriesi, H. 2016. "The Politicization of European Integration." JCMS: Journal of Common Market Studies54 (Annual Review): 32-47.

Kutter, A. 2020. "The Construction of the Eurozone Crisis: Re- and Depoliticising European Economic Integration." Journal of European Integration 42 (5): 659-676.

Laffan, B. 2014. "Framing the Crisis, Defining the Problems." Perspectives on European Politics and Society 15 (3): 266-280. doi:10.1080/15705854.2014.912395.

Laws, D., and M. Rein. 2003. "Reframing Practice." In Deliberative Policy Analysis. Understanding Governance in the Network Society, edited by M. Hajer and H. Wagenaar, 172-206. Cambridge: Cambridge University Press.

Leupold, A. 2016. "A Structural Approach to Politicisation in the Euro Crisis." West European Politics 39 (1): 84-103. doi:10.1080/01402382.2015.1081510.

Maricut-Akbik, A. 2018. "EU Politicization beyond the Euro Crisis: Immigration Crises and the Politicization of Free Movement of People." Comparative European Politics. doi:10.1057/s41295018-0113-6.

Moffitt, B. 2016. The Global Rise of Populism: Performance, Political Style, and Representation. Stanford: Stanford University Press.

Moreira Ramalho, T. 2020. "The 'Troika' in Its Own Words: Responding to the Politicisation of the Southern European Crises." Journal of European Integration 42 (5): 677-693.

Natorski, M. 2020. "United We Stand in Metaphors: EU Authority and Incomplete Politicisation of the Crisis in Ukraine." Journal of European Integration 42 (5): 733-749.

Rauh, C. 2018. "EU Politicization and Policy Initiatives of the European Commission: The Case of Consumer Policy." Journal of European Public Policy 26 (3): 344-365. doi:10.1080/ 13501763.2018.1453528.

Rauh, C., and M. Zürn. 2016. "Die Politisierung der Europäischen Union als Chance nutzen." integration 39 (1): 3-14. doi:10.5771/0720-5120-2016-1-3.

Roitman, J. 2013. Anti-Crisis. Durham. NC: Duke University Press.

Saurugger, S. 2016. "Politicisation and Integration through Law: Whither Integration Theory?" West European Politics 39 (5): 933-952. doi:10.1080/01402382.2016.1184415.

Schimmelfennig, F. 2018a. "European Integration (Theory) in Times of Crisis. A Comparison of the Euro and Schengen Crises." Journal of European Public Policy 25 (7): 969-989. doi:10.1080/ 13501763.2017.1421252.

Schimmelfennig, F. 2018b. "Liberal Intergovernmentalism and the Crises of the European Union." JCMS: Journal of Common Market Studies 56 (7): 1578-1594.

Schimmelfennig, F., D. Leuffen, and B. Rittberger. 2015. "The European Union as a System of Differentiated Integration: Interdependence, Politicization and Differentiation." Journal of European Public Policy 22 (6): 764-782. doi:10.1080/13501763.2015.1020835. 
Schmitter, P. C. 1969. "Three Neo-functional Hypotheses about International Integration." International Organization 23 (1): 161-166. doi:10.1017/S0020818300025601.

Schoen, D. A., and M. Rein. 1994. Frame Reflection: Toward the Resolution of Intractable Policy Controversies. New York: Basic Books.

Snow, D. A., and R. D. Benford. 1992. "Master Frames and Cycles of Protest." In Frontiers in Social Movements Theory, edited by C. M. Mueller and A. D. Morris, 133-155. New Haven: Yale University Press.

Snow, D. A., E. Burke Rochford, S. K. Worden, and R. D. Benford. 1986. "Frame Alignment Processes, Micromobilization, and Movement Participation." American Sociological Review 51 (4): 464-481. doi:10.2307/2095581.

Snow, D. A., and R. D. Benford. 1988. "Ideology, Frame Resonance, and Participant Mobilization." International Social Movements Research 1: 197-218.

Statham, P., and H.-J. Trenz. 2014. "Understanding the Mechanisms of EU Politicization: Lessons from the Eurozone Crisis." Comparative European Politics 13 (3): 287-306. doi:10.1057/cep.2013.30.

Voltolini, B. 2016. "Non-State Actors and Framing Processes in EU Foreign Policy: The Case of EUIsrael Relations." Journal of European Public Policy 23 (10): 1502-1519. doi:10.1080/ 13501763.2015.1085429.

Voltolini, B. 2020. "Ontological Crises, Framing and the (De)politicisation of EU Foreign Policy: The Case of EU-Israel Relations." Journal of European Integration 42 (5): 751-766.

Warren, T. 2017. "Framing the Eurozone Crisis: A Case of Limited Ambition." Journal of European Integration 40 (1): 67-82. doi:10.1080/07036337.2017.1404052.

Weiss, J. A. 1989. "The Powers of Problem Definition: The Case of Government Paperwork." Policy Sciences 22: 97-121. doi:10.1007/BF00141381.

Widmaier, W. W. 2007. "Constructing Foreign Policy Crises: Interpretive Leadership in the Cold War and War on Terrorism." International Studies Quarterly 51 (4): 779-794. doi:10.1111/j.14682478.2007.00476.x.

Williams, R. H. 2004. "The Cultural Contexts of Collective Action: Constraints, Opportunities, and the Symbolic Life of Social Movements." In The Blackwell Companion to Social Movements, edited by D. A. Snow, S. A. Soule, and H. Kriesi, 91-115. Oxford: Blackwell Pub.

Wonka, A. 2015. "The Party Politics of the Euro Crisis in the GermanBundestag: Frames, Positions and Salience." West European Politics 39 (1): 125-144. doi:10.1080/01402382.2015.1081512.

Zamponi, L., and L. Bosi. 2016. "What Crisis? European Crisis and National Contexts in Public Discourse." Politics \& Policy 44 (3): 400-426. doi:10.1111/polp.12156.

Zeitlin, J., F. Nicoli, and B. Laffan. 2019. "Introduction: The European Union beyond the Polycrisis? Integration and Politicization in an Age of Shifting Cleavages." Journal of European Public Policy 26 (7): 963-976. doi:10.1080/13501763.2019.1619803.

Zürn, M. 2018. A Theory of Global Governance. Authority, Legitimacy and Contestation. Oxford: Oxford University Press. 